\title{
Professional development of Teacher-Educators towards Transformative learning
}

Citation for published version (APA):

Meijer, M-J., Kuijpers, M., Boei, F., Vrieling, E., \& Geijsel, F. (2016). Professional development of TeacherEducators towards Transformative learning. Professional Development in Education, 43(5), 819-840. https://doi.org/10.1080/19415257.2016.1254107

DOI:

10.1080/19415257.2016.1254107

Document status and date:

Published: 25/11/2016

Document Version:

Peer reviewed version

Document license:

CC BY-NC-ND

Please check the document version of this publication:

- A submitted manuscript is the version of the article upon submission and before peer-review. There can be important differences between the submitted version and the official published version of record. People interested in the research are advised to contact the author for the final version of the publication, or visit the DOI to the publisher's website.

- The final author version and the galley proof are versions of the publication after peer review.

- The final published version features the final layout of the paper including the volume, issue and page numbers.

Link to publication

\section{General rights}

Copyright and moral rights for the publications made accessible in the public portal are retained by the authors and/or other copyright owners and it is a condition of accessing publications that users recognise and abide by the legal requirements associated with these rights.

- Users may download and print one copy of any publication from the public portal for the purpose of private study or research.

- You may not further distribute the material or use it for any profit-making activity or commercial gain

- You may freely distribute the URL identifying the publication in the public portal.

If the publication is distributed under the terms of Article 25fa of the Dutch Copyright Act, indicated by the "Taverne" license above, please follow below link for the End User Agreement:

https://www.ou.nl/taverne-agreement

Take down policy

If you believe that this document breaches copyright please contact us at:

pure-support@ou.nl

providing details and we will investigate your claim.

Downloaded from https://research.ou.nl/ on date: 26 Apr. 2023 


\section{Professional Development of Teacher-Educators towards Transformative Learning}

Accepted paper to be published in 'Professional Development in Education'

This research was conducted at Windesheim University of Applied Sciences | Campus 2-6, 8017 CA Zwolle, Netherlands

\section{Corresponding Author:}

Marie-Jeanne Meijer, Windesheim University of Applied Sciences, Movement \& Education. Campus 2-6, 8017 CA Zwolle, The Netherlands, +31.642427249, mj.meijer@windesheim.nl

\section{Authors}

Marie-Jeanne Meijer, Windesheim University of Applied Sciences, Movement \& Education. Campus 2-6, 8017 CA Zwolle, The Netherlands, +31.642427249, mj.meijer@windesheim.nl

Marinka Kuijpers, Welten Institute, Open University, Valkenburgerweg 177, 6419 AT

Heerlen, The Netherlands, +31.651427650, marinka.kuijpers@ou.nl

Fer Boei, Windesheim University of Applied Sciences, Movement \& Education. Campus 2-6, 8017 CA Zwolle, The Netherlands, +31 683357453, f.boei@windesheim.nl

Emmy Vrieling, Welten Institute, Open University, Valkenburgerweg 177, 6419 AT Heerlen, The Netherlands, +31.621112436, emmy.vrieling@ou.nl

Femke Geijsel, University of Amsterdam /Netherlands Institute of Educational Management (NSO), Linnaeusstraat 35F, 1093 EE Amsterdam, +31.642203608, f.p.geijsel@uva.nl 


\title{
Professional Development of Teacher-Educators towards Transformative Learning
}

\author{
Abstract \\ This study explores the specific characteristics of teacher-educator professional development \\ interventions that enhance their transformative learning towards stimulating the inquiry-based \\ attitude of students. An educational design research method was followed. Firstly, in \\ partnership with five experienced educators, a professional development programme was \\ designed, tested and redesigned. Secondly, a qualitative multiple case study was conducted to \\ examine the active ingredients of the designed interventions with regard to educators changes \\ in beliefs and behaviour. The study was carried out in four different educational settings in \\ which 20 educators participated during nine months. Data sources included videos, \\ questionnaires, interviews and written personal theories of practice. The analyses indicated \\ that aligned self-study interventions on a personal, peer and group level guided by a trained \\ facilitator supported the intended leaning.
}

\section{Keywords}

teacher-educators; professional development; inquiry-based attitude; educational design research; transformative learning 


\section{Professional development of Teacher-Educators towards Transformative learning}

\section{Introduction}

Due to current economic and social developments, professionals need to be able to respond quickly and adequately to new and changing circumstances more than ever (Coonen, 2006; OCW/EZ, 2009). These professionals are characterised by the ability to continuously renew their own performance throughout their professional lives based on quality information, knowledge and the experience of others (Leijnse, Hulst, \& Vroomans, 2006; Vijlder, 2007; Hargreaves \& Fullan, 2012). Both international organisations (Cochran-Smith \& Zeichner, 2010) and the Dutch Education Council (2014) assume that having an 'inquiry-based attitude' contributes to this ability to innovate and to the circulation of knowledge, which will boost the economy (Mourshed, Chijioke, \& Barber, 2010). Based on this assumption, the Dutch Education Council (2014) states that teacher education should educate teachers with an inquiry-based attitude (IA).

According to Snoek, Swennen, \& van der Klink (2011) intensive international exchange of learning by educators will contribute to the professionalism of teacher educators. Until now, however, there have been no empirical studies that provide specific insight into how teachereducators (hereinafter: “educators') can enhance the development of the IA of teachers-intraining (hereinafter: "students"). Moreover, this general lack of knowledge in teacher education research concerning ingredients, conditions or contexts that may have a positive impact on what and how educators learn (Cochran-Smith \& Zeichner, 2010; Lunenberg, Dengerink, \& Korthagen, 2014), complicates the development of educators. 
The aim of the study is to understand the specific characteristics of professional development interventions that encourage the deep learning of educators. In order to do this, a professional development programme was designed in collaboration with these educators (Biesta, 2007; McKenney \& Reeves, 2013). The subject of this program was enhancing the inquiry- based attitude of their students. We used the 'Educational Design Research' method (McKenney \& Reeves, 2013) in which a study is conducted in an authentic educational setting with practitioners to explore how and why which kinds of approach truly help solve 'real problems' (Van den Akker, Gravemeijer, McKenney, \& Nieveen, 2006). This collaboration of researchers with practitioners is also referred to as 'engaged scholarship' (Van de Ven, 2007) and according to Kessels (2012) and Martens (2009) this approach supports innovation processes in teaching practice, whilst simultaneously contributing to professional development.

\section{Theoretical background}

First of all, this section describes the already known results of effective ingredients for professional development of TEs from a theoretical perspective and, secondly, recent insights in the field of stimulating IA.

\section{Professionalising Teacher-Educators}

Educators are expected to train teachers with an IA (Onderwijsraad, 2014). When designing a professional development programme for educators that help them to stimulate the development of IA in students, it is not possible to rely on scientifically validated training interventions. This is because systematic professional development training for educators in and outside the Netherlands is either severely limited or lacking altogether (Cochran-Smith \& Zeichner, 2010; Dengerink, Lunenberg, \& Kools, 2015). 
In order to contribute to the professionalisation of the profession of educator, Lunenberg et al. (2014) defined six professional roles based on a review study, namely: teacher of teachers, researcher, facilitator, curriculum developer, gatekeeper and bridge builder. For the professional development programme to be designed to promote the IA of students, the role of 'teacher of teachers' is especially important. The main characteristics are: promoting active learning, being a role model and explaining and legitimising being a role model. The latter does not occur very often, because it is so complicated that educators 'do not know what they know at a conscious level and may have had few experiences of articulating their knowledge of practice either for themselves or others' (Berry, 2009, p. 307). With regard to the professional development of educators, Lunenberg et al. (2014) distilled some useful generic features: learning from and with peers has a particularly positive effect; research into one's own practice also turns out to be effective, and training must support learning and be suitable for the educators. Empirical knowledge about specific professional development features for educators is not available, however.

Because of the lack of specific knowledge about the professional development of educators, we consider knowledge about the professionalisation of teachers in general relevant as well. Here too, however, there is a lack of a thorough evidence base for the specific features of professional development interventions (Desmione, 2009; Van Veen, Zwart, Meirink, \& Verloop, 2010; Vermunt \& Endedijk, 2011). Generic characteristics related to effective professional development interventions were found, however (Van Veen et al., 2010). These characteristics correspond to the generic professional development features provided by Lunenberg et al. (2014). These include: Learning with and from peers; Studying one's own daily classroom practice and Learning support. As a precondition, professional development should be in line with school policy and given adequate time (van Veen et al. 2010). 


\section{Learning at a Professional Identity Level}

Because the professional identity of educators has implications for taking up their professional roles (Newberry, 2014), the overarching principle of professional development concerns the importance to focus on changes in beliefs and behaviour related to personal growth at a professional identity level (Geijsel \& Meijers, 2005; Illeris, 2014; Kelchtermans, 2009). Although the general view is that beliefs and behaviour characterise the identity and that personal growth should focus on both, there is still much uncertainty about the exact nature of the relationship between beliefs and behaviour (Taylor, 2007; van der Schaaf, Stokking, \& Verloop, 2008). Identity is a complex concept with a complicated structure, which does not simply change under the influence of professionalisation (Beijaard, Meijer, \& Verloop, 2004; Dinkelman, 2011). Development psychology has demonstrated that identity consists of a part that is stable and insensitive to change and a part that is sensitive to change (e.g. Day, Kington, Stobart, \& Sammons, 2006). In order to determine this difference in stability in relation to learning, Illeris (2014) developed a model in which the general structure of identity is worked out on the basis of on the available learning and personality theories. This three-layer model helps to explain which expectations are realistic with regard to changes in beliefs and behaviour in relation to the intended level of learning. The 'preference layer' is the least stable and includes preferences and routines with regard to acting, thinking and feeling in everyday situations. The 'personality layer' includes values, attitudes, beliefs, behavioural patterns, manners and attitude and is relatively stable, but can be influenced by professionalisation. The 'core identity layer' includes personality traits and is therefore so stable that professionalisation hardly influences it (Boekaerts, 1996; McCrae et al., 2000).

The type of learning we are aiming for is learning that brings about changes in the socalled personality layer. In order to achieve this learning, most professional development 
literature greatly emphasizes 'deep learning' (c.f. Fullan \& Langworthy, 2014; Van Veen, et al., 2010). However, the intended level of learning in this study is 'transformative learning', as introduced by Mezirow (1991). This learning is characterised as "not something to be remembered and recalled, but something that has become part of the person" (Illeris, 2009, p. 142). According to Flores and Day (2006), teacher training even involves "in essence, the (trans)formation of the teacher identity" (p. 220). Transformative learning is therefore considered to be the highest level of deep learning and requires critical reflection (Illeris, 2014; Mezirow \& Taylor, 2009). Critical reflection involves the deconstruction and reconstruction of personal beliefs, which can lead to new beliefs (Kember et al., 2000; Mezirow \& Taylor, 2009). Although the impact of critical reflection on the intended learning is generally recognised (e.g. Avalos, 2011; Dyment \& O'Connell, 2011), this does not mean that a change in beliefs automatically leads to matching behaviour (Taylor, 2007; van der Schaaf, et al., 2008). However, the meta-analysis of Webb and Sheeran (2016) revealed a positive causal relationship between intentions and behaviour. This indicates that interventions with greater impact in beliefs and intention engender greater impacts on behaviour.

\section{Stimulating an Inquiry-based Attitude}

In this study we are particularly interested in what specific interventions in the professional development of educators affect their stimulation of the IA of students. In both scientific and practical publications IA is generally used as a container concept that refers to a broad set of attributes that is associated with (1) personality traits such as openness and curiosity; (2) characteristics of a reflective, deep-learning practitioner with a critical mind and (3) research skills such as the systematic use of knowledge and working and thinking analytically (e.g. Bruggink \& Harinck, 2012; Cochran-Smith \& Lytle, 2009; Leeman \& Wardekker, 2014; 
Mason, 2009). In order to operationalise the container concept of IA into a well-founded concept that offers educators insight into its characteristics, Author 1, Author 2, Author 3, Author 4 and Author 5 (2016) conducted a multiannual empirical study into the developable features of IA. The present study applies this operationalisation, in which IA is characterised as a construct with an internal and an external dimension that complement each other. They are referred to as IA-Internal and IA-External.

IA-Internal concerns the ability of teachers to gain 'new modes of understanding' about themselves, about knowledge and about the context, with the purpose to work on/refresh their professional behaviour (Meijer, Geijsel, Kuijpers, Boei, \& Vrieling, 2016). This ability is based on reflection, a key aspect of IA-Internal. Four levels can be distinguished within reflection, namely: (1) habitual action: acting routinely; (2) understanding: comprehending theoretical concepts; (3) reflection: intellectual and affective activities to facilitate thinking about personal professional practice experiences and (4) critical reflection: the deconstruction and reconstruction of personal beliefs, which can lead to new beliefs (Kember et al., 2000; Lethbridge, Andrusyszyn, Iwasiw, Laschinger, \& Fernando, 2013). The latter three levels are related to a deep approach to learning (Leung \& Kember, 2003) and relevant in the present study.

IA-External relates to active knowledge-sourcing behaviour focused on professional development in response to specific questions and/or problems (Meijer et al., 2016).

This means that a person actively seeks new relevant knowledge sources in response to specific questions. IA-External has strong similarities with what is described as 'looking past one's own professional borders' and 'learning from others' in educational and organisational studies (Leijnse et al., 2006; Hargreaves \& Fullan, 2012). In addition, this concept is similar to the intellectual exploratory behaviour or epistemic curiosity described in psychology (Litman \& Spielberger, 2003; Reio, Petrosko, Wiswell, \& Thongsukmag, 2006). 
Knowledge management literature also defines IA-External as: "intentional actions taken to locate and access others' expertise, experiences, insights, and opinion" (Gray \& Meister, 2006, p. 144).

\section{Research questions}

In order to examine the extent to which and the manner in which the specifically designed interventions in the professional development programme support the development of educators at the level of transformative learning with regard to stimulating an inquiry-based attitude in students, we seek to answer the following two questions:

1. To what extent and in what way do the designed professional development interventions support the transformative learning of educators?

2. How do these interventions influence changes in beliefs and/or behaviour of educators with regard to the stimulation of an inquiry-based attitude in students?

Before we can start finding the answers to these questions, we will first describe the design of the professional development programme.

\section{Design of the Professional Development Programme}

The next section describes the theoretical design of the professional development programme. In this design the two key preconditions (1) 'being in line with the policy of the university' and (2) 'adequate time for professional development' (Van Veen et al., 2010) have been complied with. The subject of our professional development is stimulating IA of students, which is in line with the first precondition because the policy of the university is to promote IA as a spear point. In line with the second precondition, participants will be given 30 hours 
of professionalisation time by the management for seven 3-hour peer-meetings which are distributed evenly over 9 months (See Figure 1. Overview intervention display).

The design of the specific interventions is based on the following three generic design principles: 'learning with and from peers'; 'studying one's own practice' and 'supporting transformative learning'. These will be described below. From now on the professional development programme will be referred to as 'Teacher-educator Inquiry-based Professional development Programme' (TIPP).

\section{Learning with and from Peers}

The most powerful driver for educational innovations is learning from peers (Mourshed, Chijioke, \& Barber, 2010). Hord (1997) refers to learning from peers as 'professional community', which is all about the shared responsibility of practitioners to develop a shared vision on meaningful practice questions with the aim of improving this practice. According to Hargreaves and Fullan (2012), this type of learning is fuelled by actively collaborating with peers, studying practice, and discussing both scientific knowledge and personal expert knowledge about effective teaching. A prerequisite for this kind of professional learning is 'critical friendship' with the emphasis on 'friendship', meaning 'equality', 'trust', 'openness' and 'vulnerability' (Schuck, Aubusson, \& Buchanan, 2008). In order to realise learning from and with peers on the basis of critical friendship during TIPP, it was decided to work with relatively small groups of five colleagues (peers) who know each other and participate on a voluntary basis.

\section{Studying one's own practice}

An intervention-set with 'Theory of Practice' was designed in order to explore the beliefs that the educators utilise as a framework for the way in which they act (Miles, Huberman, \& 
Saldaña, 2013) and promote professional self-understanding based on this exploration (Berry, 2009). This intervention set consists of three sub-interventions that we refer to as (1) 'personal' (2) 'peer' and (3) 'group'. First of all, a personal theory of practice is written prior to TIPP (Kelchtermans, 2009) which demands a critical exploration of one's own profile as an educator who educates teachers with an IA. The format in which this is written can be decided by yourself, the content is based on guiding questions about aspects such as one's own beliefs, how these beliefs originated and how they are related to the beliefs of 'others' and to the gained knowledge. Secondly, the theories of practice are sent to the peers prior to the peer-meeting, so they can prepare reflective and clarification questions. Thirdly, the theories of practice are discussed at the group meeting. At the end of TIPP this theory of practice is written once again to reveal any changes in beliefs.

In order to explore educator behaviour with regard to stimulating the IA of students, the intervention set 'Video Analysis' was designed. This also consists of three subinterventions: (1) 'personal', (2) 'peer' and (3) 'group'. In the week prior to TIPP each participant can choose one of their lessons, which will then be recorded on video. First of all, the participants' own behaviour is analysed by themselves by using the same analysis codes based on theory. The codes concerned their promotion of IA-Internal (i.e. understanding, reflection and critical reflection) and IA-External (i.e. knowledge-sourcing behaviour). Secondly, the educators also analysed a video of one peer. Thirdly, the analysis dilemmas are explored during the group meeting by using therefore selected video clips. This approach is supported by the meta-analysis of Fukkink, Trienekens and Kramer regarding video feedback (2010), which shows that video analyses and discussing dilemmas can have a positive effect on learning, provided that the psychological impact of 'self-confrontation' is taken into account. The use of this approach within a professional learning community is supported by the research of Schuck et al. (2008), which shows that peer observations in combination with 
professional learning conversations promote critical reflection. At the end of TIPP a second video is recorded and analysed to reveal any changes in behaviour.

\section{Supporting Transformative Learning}

In order to support transformative learning, five interventions were implemented. Firstly, transformative learning is supported by 'trained facilitators' who co-designed, tested and improved TIPP as an expert group and who are prepared for their role of facilitator during two half-day trainings sessions (McKenney \& Reeves, 2013; Van den Akker, et al., 2006). These facilitators practised offering feedback: "what progress is made towards the learning objective?” and 'feed forward'; “what action needs to be undertaken to make better progress?” (Hattie \& Timperley, 2007, p. 86). They also practised asking critical reflective questions aimed at understanding, explaining and improving or rebalancing behaviour and beliefs (Mezirow \& Taylor, 2009; Taylor \& Jarecke, 2009). Such guided reflection by facilitators during group meetings has proved to be helpful in supporting self-study (Lunenberg, Zwart \&Korthagen, 2010). Finally, they practised functioning as a role model for elaborating on and legitimising their own actions (Lunenberg, et al., 2014). In order to ensure the continuity of the learning process, the facilitator draws up process reports of the group meetings that are read prior to the meetings.

Secondly, the participants formulate a personal 'learning objective' to give direction to their learning (Segers \& Dochy, 1999). Thirdly, 'reflective memos' (Akister et al., 2003; Ovens, 2011) are written during and after teaching and discussed during the group meetings. Fourthly, 'a personal log' is written to support reflection (Verkuyl \& Korthagen, 1999). And fifthly, 'reading and discussing theory' is done to support the conceptual understanding of stimulating IA (Hargreaves \& Fullan, 2012). 


\section{Methodology}

This qualitative Educational Design Research was carried out as a multiple case study within the context of four different teacher training courses (bachelor and master level) at a professional university in Central Netherlands. The investigation followed the generic Educational Design Research model as described by McKenney (2013, p. 78) and was characterized by iterative cycles of design, evaluation and redesign. The research consisted of two phases: a preparatory phase and a main study phase. The preparatory phase consisted of designing, testing, evaluating and improving the theory-based professional development programme as described in paragraph 4 together with an expert group. The resulting design (see Figure 1. Overview intervention display) was implemented during the main study.

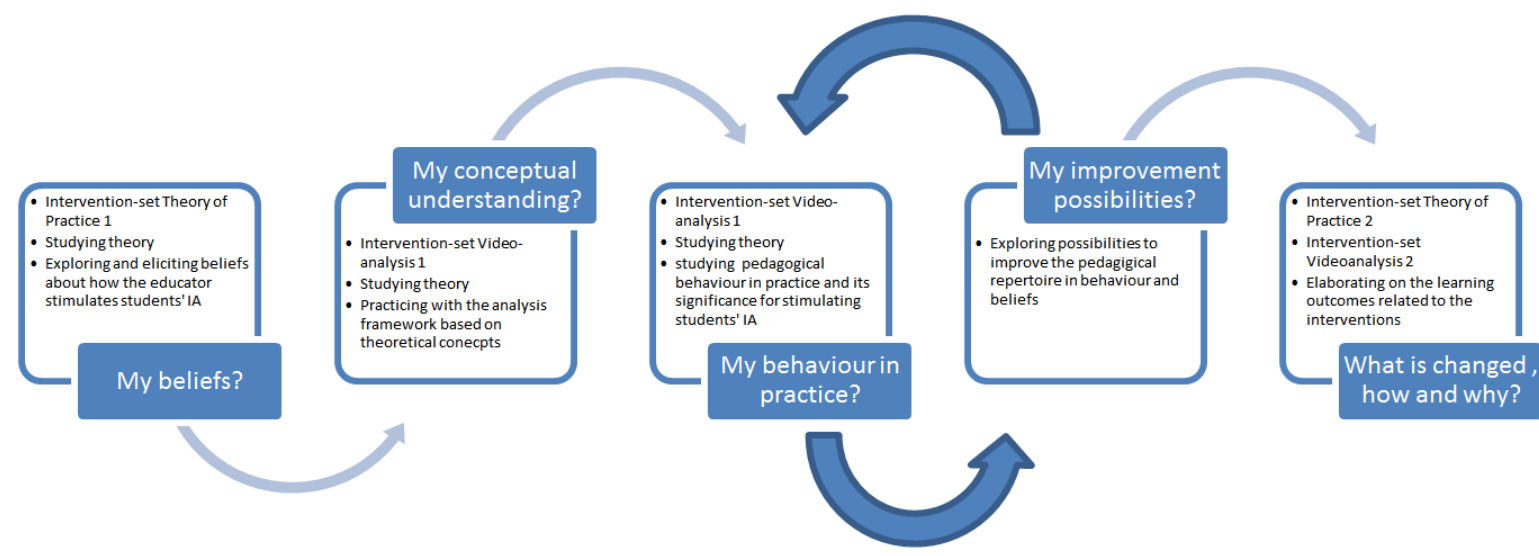

\begin{tabular}{|c|c|c|c|c|}
\hline meeting 1 & meeting 2 & meeting 7 \\
Learning with and from peers, guided by a trained facilitator &
\end{tabular}

Figure 1 Overview intervention display

The main study phase consisted of four parallel case studies in which four fairly homogeneous groups of TEs at four different teacher training courses were followed during TIPP over a period of nine months. In order to understand what TIPP means for professional 
development, we explored which interventions worked and how and why, and which parts of the interventions needed improvement (McKenney \& Reeves, 2013; Swanborn, 2010). The main study phase contributed to answering both investigation questions.

Reliability was improved by safeguarding the researcher's objectivity as much as possible. The researcher only facilitated TIPP in the try-out stage, while the trained facilitators did this during the main study (van Aken \& Andriessen, 2011). Moreover, four different data sources were used to get an as complete picture as possible of any changes in the theory that a person may endorse (i.e. beliefs) and in a person's behaviour (Argyris, 2004). Behavioural observations (i.e. videos) were combined with analyses of theories of practice, written evaluations and in-depth interviews. The interviews were conducted by the researcher and an assistant and were taped. During analyses the reliability was improved by coding with two researchers together, so that it could be ensured that the data were interpreted properly (Patton, 2015). In addition, the analysis was both deductive and inductive during the analysis phase. Deductive with a pre-set analysis framework based on the interventions, the theory regarding the IA (i.e. understanding, reflection and critical reflection and knowledge-sourcing behaviour) and the theory with regard to transformative learning. Inductive through open coding non-coded material to find any unexpected variables or themes and also to expose any supplemental functions of the design (Baldwin \& Clark, 2000).

In order to improve the validity, the researcher discussed any threats to validity with the facilitators during the main study after each TIPP meeting (Ropes, 2010). Examples of this were: not filming on time, loss of two participants, adopting the conceptual framework at a different pace. During these meetings various approaches to facilitation were explored to coordinate as well as possible. Because educational practice makes it impossible to control all variables, the aim was to produce results that had the nature of plausible interpretations and transferable knowledge (Ropes, 2010; van Aken \& Andriessen, 2011). This means that it is 
plausible that the knowledge about the interventions evaluated in this specific context can be used in other relevant contexts.

\section{Participants}

\section{Preparation phase of participants}

These participants formed the expert group $(\mathrm{N}=5)$, consisting of experienced educators from a master programme (experience 8-18 years, age 43-58, mean age 53.3, gender 5 female) who participated out of personal interest. They took part with the knowledge that they would participate first of all as co-designer and then as facilitator. They were given 30 hours for the preparatory phase and 60 hours for the main study phase.

\section{Main study of participants}

These participants $(\mathrm{N}=20)$ were experienced educators from two master's programmes (hereinafter referred to as M1 and M2) and two bachelor's programmes (hereinafter referred to as B1 and B2) who participated on a voluntary basis (gender: 10 male, 10 female, age 2968, mean age 50.8, experience $4-25$ years). The participants formed four groups (M1, M2, B1 and B2) of five colleagues. They were given 30 hours and were recruited through an email from the management. Further explanation was given during a team meeting. Two participants quit during TIPP due to personal circumstances and have not been included in the analysis.

\section{Data sources main study}

In order to explore the extent to which interventions (A) supported the professional learning of educators and whether they influenced (B) changes in beliefs and/or (C) behaviour of the educators, four data sources were used (see Table 1) 


\begin{tabular}{|l|l|l|l|}
\hline Analysis main themes & $\begin{array}{l}\text { A. Experienced } \\
\text { learning support } \\
\text { Interventions }\end{array}$ & B. Change in beliefs & $\begin{array}{l}\text { C. Change in } \\
\text { behaviour }\end{array}$ \\
\hline Questionnaire TIPP sources & $\mathrm{x}$ & $\mathrm{x}$ & $\mathrm{x}$ \\
\hline Theory of practice 1 \& Theory of practice 2 & & $\mathrm{x}$ \\
\hline Video 1 \& Video 2 & & $\mathrm{x}$ & \\
\hline Interview TIPP & $\mathrm{x}$ & & \\
\hline
\end{tabular}

Table 1. Main themes analysis and data sources.

\section{Questionnaire TIPP}

This questionnaire was related to the experienced learning support concerning the interventions and the change in beliefs (Table 1, row 1, column A and B). Participants were first asked to give a general impression of their learning results. A sample question was:

'What are the main insights you gained from TIPP?' For each intervention the participant was asked about how their beliefs were influenced, what this meant, and if there were any suggestions for improvement. A sample question was: 'How did writing a theory of practice affect your beliefs with regard to training teachers with an IA?' The questionnaire was completed prior to the last group meeting. The aim of this approach was to explore the experiences and perspectives thoroughly and preparing the educators as well as possible for the evaluation interview (Seidman, 2013).

\section{Theories of practice}

In order to explore changes in beliefs (Table 1, row 2, column B) as a framework for actions, educators wrote a personal theory of practice regarding educating teachers with an IA prior to and after TIPP. 


\section{Videos}

In order to explore changes in behaviour (Table 1, row 3, column C), videos were recorded prior to and after TIPP (30-50 minutes long, depending on the class). The videos were transcribed prior to the analysis.

\section{Interview TIPP}

Individual semi-open in-depth interviews were conducted to explore the learning experiences of the educators and their significance with regard to beliefs (Table 1, row 4, column A and B). The interviews were structured according to the structure of Seidman (2013), the topics of Silverman (2011) and the question categories of Merriam (1998). The questions were flexible and implemented just-in-time during an interview that lasted 30-45 minutes and had the following structure: (1) introducing and explaining the procedures; (2) exploratory depersonalised questions based on an ideal position, such as: 'What do you think the ideal teacher-educator who encourages an optimum inquiry-based attitude looks like?' (3) Interpretation questions to explore the participant's own opinions and reasoning, such as: 'To what extent will your students have noticed that you were participating in TIPP?'

\section{Data Analysis}

The qualitative exploratory analyses of the data from the main study were performed using QDA miner (Cuva, 2014). There were three separate analyses: (A) the kind of learning support experienced in the interventions; (B) changes in beliefs and (C) changes in behaviour. As units of analysis we used TIPP groups as cases (i.e. M1, M2, B1, B2). Coding was based on meaningful units/passages, with one code per dimension of the IA (i.e. Internal or External) as a starting point. When coding IA-Internal (i.e. understanding, reflection and critical reflection) coding was always based on the highest possible level of reflection. 
For the interpretation of the results in terms of the efficacy of the interventions we used a variable-by-variable matrix based on an example by Miles, Huberman and Saldaña (2013, p. 224). Our first objective was to understand the efficacy and 'inter-relationship' between the interventions. We then critically examined whether the image at group level matched the image of the sub-units within the cases (i.e. participants) (Swanborn, 2010). Interventions that were found to be supportive by at most five participants were not analysed. For the interventions that were considered to be supportive, based on the relationships between the frequencies and the interpretation of the content of the statements, the extent to which interventions were supportive and the active ingredients were charted. Since it was not expected that participants would indicate the significance with regard to learning for all interventions, we also included 'generic' statements about the interventions in the analysis. Representative quotes from the participants were used to illustrate the results. A number of these quotes fit several interventions. However, every quote was only used once in order to draw an as rich picture as possible. Finally, the extent to which interventions affected change was explored by charting changes in the variations of the intervention repertoire on the one hand and changes in frequencies within the repertoire on the other hand.

\section{Results research question one}

Regarding research question 1, table 2 shows a quantitative summary with the results of the support of the interventions on learning. The subsequent sections explain these results: what worked in this intervention, why and to what extent is transformative learning supported? If relevant, improvement suggestions are made. A qualitative summary of the supporting interventions and their active ingredients is given in Table 3 


\begin{tabular}{|c|c|c|c|c|c|c|}
\hline \multicolumn{2}{|c|}{$\begin{array}{l}\text { Interventions' support on } \\
\text { learning }\end{array}$} & \multirow{2}{*}{$\begin{array}{c}\begin{array}{c}\text { General } \\
\text { learning } \\
\text { support } \\
\text { (group } \\
\text { level) }\end{array} \\
100 \%\end{array}$} & \multirow{2}{*}{$\begin{array}{c}\begin{array}{c}\text { General } \\
\text { learning } \\
\text { support } \\
\text { (sub-unit } \\
\text { level) }\end{array} \\
100 \%\end{array}$} & \multirow{2}{*}{$\begin{array}{c}\begin{array}{c}\text { Transformative } \\
\text { Learning } \\
\text { (sub-unit level) }\end{array} \\
22.2 \%\end{array}$} & \multirow{2}{*}{$\begin{array}{c}\begin{array}{c}\text { Specific } \\
\text { learning } \\
\text { support }\end{array} \\
\text { IA-Intern } \\
\text { (sub-unit } \\
\text { level) } \\
11.1 \%\end{array}$} & \multirow{2}{*}{$\begin{array}{c}\text { Specific learning } \\
\text { support } \\
\text { IA-Extern } \\
\text { (sub-unit level) } \\
\\
0 \%\end{array}$} \\
\hline $\begin{array}{l}\text { Learning } \\
\text { with and } \\
\text { from } \\
\text { peers }\end{array}$ & $\begin{array}{l}\text { Learning with and } \\
\text { from } \\
\text { peers }\end{array}$ & & & & & \\
\hline \multirow{2}{*}{$\begin{array}{l}\text { Studying } \\
\text { one's } \\
\text { own } \\
\text { practice }\end{array}$} & $\begin{array}{l}\text { Intervention-set } \\
\text { Theory of } \\
\text { Practice }\end{array}$ & $100 \%$ & $94.4 \%$ & $27.7 \%$ & $38.8 \%$ & $0 \%$ \\
\hline & $\begin{array}{l}\text { Intervention-set } \\
\text { Video Analysis }\end{array}$ & $100 \%$ & $83.3 \%$ & $44.4 \%$ & $38.8 \%$ & $0 \%$ \\
\hline \multirow[t]{4}{*}{$\begin{array}{l}\text { Learning } \\
\text { support }\end{array}$} & $\begin{array}{l}\text { General quality } \\
\text { facilitator }\end{array}$ & $100 \%$ & $83.3 \%$ & $5.6 \%$ & $5.6 \%$ & $0 \%$ \\
\hline & Studying theory & $100 \%$ & $88.3 \%$ & $5.6 \%$ & $0 \%$ & $5.6 \%$ \\
\hline & $\begin{array}{l}\text { Formulating a } \\
\text { personal learning } \\
\text { objective }\end{array}$ & $75 \%$ & $62 \%$ & $0 \%$ & $0 \%$ & $0 \%$ \\
\hline & TIPP as a whole & $100 \%$ & $94.4 \%$ & $94.4 \%$ & $61.1 \%$ & $5.6 \%$ \\
\hline
\end{tabular}

Table 2. Quantitative results interventions' support on learning

\section{Learning with and from peers}

All groups and all participants experienced 'learning with and from peers' as generically supportive for professional development (see Table 2, row 1 and Table 3, row 2-3). It is explicitly stated by $66.7 \%$ (of this $100 \%$ ) that the enhancement of their own reflection is one of the results. Learning with and from peers is often mentioned in relation with another intervention, for example: "The fact that colleagues view my recordings also results in some degree of reflection: why do I do things the way I do? What is the reason? What are my 'blind spots?" (Reinier, M2). According to the participants, learning together provides support because (summarised): people 'force' each other to take a step back and examine themselves, it offers the opportunity to flesh out specific concepts together, to learn from each other by 'looking into each other's kitchen', and compare themselves with someone else and discuss this. These threads are a common theme in the example quotes for other interventions in the 
sections below. As a particular supportive aspect of learning together $27.7 \%$ of the participants mentioned 'safety'. Herbert (B1) illustrates this as follows: "I feel inspired and secure $[\ldots]$ in an atmosphere of trust and openness." It was found that $22.2 \%$ of participants referred to learning together in relation to transformative learning, as illustrated by Anna (M1): "thinking things through in a focused manner and exchanging thoughts with colleagues are of particular value. Previously, I was more in 'do mode', this process forced you to have a good look at what you were doing, which was great. It does reflect in your behaviour in the end."

These results from the main study corresponded with the experiences of the expert group during the try-out: "Thanks to the discussions within the group I have made a better connection with my work concept. My teaching behaviour has matured" (Hennie).

\section{Studying one's own practice}

\section{Intervention set 'Theories of practice'}

Participants in all groups, and $94.4 \%$ of all participants, stated that the exploration of 'beliefs' through the intervention set 'theories of practice' supported learning (See Table 2, row 2 and Table 3, row 3-4). According to the participants, this 'worked' because it encouraged the recalibration or adjustment of their own beliefs and/or behaviour: "By writing a personal theory and discussing it, I thought about how I educate for the first time in my life and discovered recurring themes" (Youp, M1). Writing was most frequently mentioned as being supportive (88.9\%), while 38.8\% mentioned reading theories/having their theories read by 'peers' and $44.0 \%$ stated that discussions in the group enhanced further elaboration and reflection. In this intervention set there was a relationship with transformative learning in $38.8 \%$, of which $87 \%$ concerns IA-Internal. This learning related to changing 'beliefs' regarding (critical) reflection and resulted in a change in how people viewed their pedagogical 
approach. Dave (M1) illustrates this change: "I now allow students to express, substantiate and share their views as much as possible. In this way they get a greater understanding of their theories of practice. This is a precondition to figure out if and how adjustment is needed." The experiences of the expert group in the try-out match the results in the main study.

The analysis showed that writing the second theory at the end of TIPP had relatively little significance. Only $16.6 \%$ wrote a complete new version, while $55.6 \%$ commented and adjusted their first version. The remaining $27.7 \%$ indicated no changes and therefore did not write a second version as illustrated by Dave (M1): "I have not rewritten my theory of practice [...] if I'd been 25, I would probably have learned more from this intervention [...] I'm $60[\ldots]$ My theory represents a deeper layer, [...] it goes deeper than the level of action, at which I still have things to learn." When asked, most respondents indicated that the workload at the end of the school year stopped them from rewriting the theory of practice.

\section{Intervention set 'Video Analysis'}

Studying one's own 'behaviour' in practice through the intervention set 'Video Analysis' was considered to be supportive by $100 \%$ of the groups and $83.3 \%$ of the participants (See Table 2, row 3 and Table 3, row 5-7). Working with Video Analysis revealed discrepancies between how people think that they behave and their actual behaviour. It also reveals incongruities between how one feels one should behave and how one actually behaves. The quote by Miranda (M2) illustrates this: "Yes, conceptual enhancement and personal confrontation with how do we actually want to do it in practice and what do we actually see?"

The participants indicated that self-analysing and analysing videos from peers and vice versa intensified personal scrutiny and enhanced reflecting about their own pedagogical approach. They also stated that sharing the videos and group discussions about dilemmas 
resulted in conceptual enhancement and a joint clarification of concepts. This is illustrated by Michel (B2): "Then [when viewing videos] it really emerged that we talked a lot, and that we tended to push students in a direction that we had in mind. And once we'd clarified concepts such as 'reflection' and 'critical reflection' and 'understanding', and reflected about the differences between them, it turned out that I, and other colleagues too, often provided 'the' answer that we had in our mind without allowing our students to think about it. At that moment I became very aware of the fact that I really needed to do this less often in order to get students engaged in "critical reflection."

Personal analysis was considered to be supportive most frequently $(66.7 \%)$, followed by peer analysis $(61.1 \%)$ and group analysis $(44.4 \%)$. This intervention set was mentioned most often in relation to transformative learning (44.4\%), which concerned IA-Internal. This experience corresponds with the experience of the expert group during the try-out: "Through the analysis of actual behaviour and the behaviour of others on video I gained more tools for getting students to reflect more deeply and focus more on their curiosity" (Hennie). An improvement suggestion for this intervention was to film shorter clips, because the analyses took too much time.

\section{Learning Support}

Five interventions were also implemented to support learning in a generic sense and transformative learning in a specific sense. With regard to these interventions, only 'facilitator', 'studying theory' and 'personal learning objective' were stated to be supportive. Only three participants stated that reflective memos were supportive and nobody mentioned writing a personal log as being supportive. Below we will discuss the interventions that were regarded as being supportive. 


\section{Qualities of facilitators}

All groups and $83.3 \%$ of the participants considered the facilitator (See Table 2, row 4 and Table 3, row 8) to be supportive for learning because of their ability to ask reflective questions, continue asking questions and encourage participants to define things carefully, create a flexible balance between controlling and providing room without losing sight of the objective, although this depended on the group, summarise, refrain from judging and because they could appreciate. This is illustrated by the following quotes: "She is continuously setting an example with in-depth questions. Focusing and carefully dividing her attention. Responding to questions by asking more questions. Understanding the hectic pace of our lives" (Ellert, B2); "Her discussion techniques, that is to say, continually asking questions, reformulating, encouraging people to explain their opinions $[\ldots]$ in a neutral way, were very skilled" (Tosca, B1).

\section{Studying theory}

Participants in $100 \%$ of the groups and $88.3 \%$ of the participants regarded the offered theory as being supportive (See Table 2, row 5 and Table 3, row 9), because it offers background information on the one hand (44.4\%) and is significant for professional development on the other hand (38.8\%). Reinier (M2) illustrates this as follows: "Reading articles creates something of an inner dialogue: a conversation with yourself". Interestingly, only $22.2 \%$ of the participants read everything, 5.6\% read nothing and $72.2 \%$ read $1-3$ sources. A possible explanation for 'not reading everything' was given by participant John (B1): "Mainly due to time constraints I only read one article". Only one participant associated 'studying theory' with transformative learning: "Yes, I am now more aware of the significance of basing things on sources. This has definitely been stimulated" (Carla, M2). 
A suggestion for improvement was to focus more on reading and discussing the theory together.

\section{Formulating a personal learning objective}

Formulating a personal learning objective (See Table 2, row 6 and table 3, row 10) was regarded as being supportive by $62 \%$ of the participants, because it provides a learning direction, as illustrated by Reinier (M2):"'by formulating a personal learning objective, you create focus: what do I want; and why?" This corresponds with the experience of the expert group.

\section{TIPP as a whole: the whole is more than the sum of its parts}

Not all learning outcomes could be attributed to specific interventions. The sum appears to be more than the parts (See Table 2, row 7). All groups and $94.4 \%$ of the participants experienced transformative learning. In $65 \%$ of the participants this constituted changes in beliefs with regard to reflection and critical reflection, therefore IA-Internal. There were no notable differences between the groups. Only $5.8 \%$ of the $94.4 \%$ constituted changes in beliefs with regard to IA-External (i.e. knowledge-sourcing behaviour). All groups provided examples concerning their transformative learning: "Perhaps they also noticed that I ask more questions than before and that I am also more aware. I also tend to ask students about their views more often" (Anna, M1); "[During the lessons] I make more room to move from reflection towards critical reflection" (Alette, M2); "Never before have I been this aware of the way various types of interventions/questions can affect the thought process of students" (Melinda, B1); "I have managed to develop myself and my students professionally thanks to the transfer of knowledge and experience between us ... I think that they [the students] believe that I have created peace and quiet and room for them to formulate their thoughts and 
views and continue ask questions about them. I only realised this year that reflection is

actually the basis of an inquiry-based attitude. I used to regard them as two separate matters,

but now I see the connection" (Saskia, B2).

\begin{tabular}{|c|c|c|c|}
\hline Generic interventions & Specific interventions & Active ingredients & Result \\
\hline \multirow[t]{3}{*}{$\begin{array}{l}\text { Learning with and from } \\
\text { peers }\end{array}$} & Critical friendship & $\begin{array}{l}\text { 'Looking into each other's } \\
\text { kitchen' and being able to } \\
\text { compare oneself to } \\
\text { colleagues } \\
\text { Critical dialogues about } \\
\text { each other's beliefs and } \\
\text { behaviour. }\end{array}$ & $\begin{array}{l}\text { Taking a step back to look at } \\
\text { one's own beliefs and } \\
\text { behaviour. } \\
\text { Encouraging (critical) } \\
\text { reflection and perhaps } \\
\text { experimenting with new } \\
\text { behaviour or confirmation of } \\
\text { one's own approach. }\end{array}$ \\
\hline & & $\begin{array}{l}\text { Critical discussions about } \\
\text { the conceptual meaning of } \\
\text { key concepts }\end{array}$ & Shared vision \\
\hline & Safety & $\begin{array}{l}\text { Because of the safe setting } \\
\text { people are not afraid to be } \\
\text { critical }\end{array}$ & $\begin{array}{l}\text { Daring to learn/be } \\
\text { vulnerable }\end{array}$ \\
\hline \multirow[t]{5}{*}{ Studying one's own practice } & Theory of Practice personal & $\begin{array}{l}\text { Elaborating on personal } \\
\text { views and expectations } \\
\text { about one's own behaviour } \\
\text { in practice }\end{array}$ & $\begin{array}{l}\text { Elaborating on one's own } \\
\text { working theory, discovering } \\
\text { one's own 'common theme' }\end{array}$ \\
\hline & $\begin{array}{l}\text { Theory of Practice } \\
\text { peers/group }\end{array}$ & $\begin{array}{l}\text { Critical dialogue and } \\
\text { discussion after reading one } \\
\text { another's theory of practice } \\
\text { Finding out about other } \\
\text { people's views and } \\
\text { discussing them } \\
\text { Further elaborating on one's } \\
\text { own beliefs and views in } \\
\text { response to the questions of } \\
\text { peers }\end{array}$ & $\begin{array}{l}\text { More informed personal } \\
\text { theory of practice and/or } \\
\text { modification of the theory of } \\
\text { practice } \\
\text { Discovering joint patterns } \\
\text { Contributes to the } \\
\text { development of a shared } \\
\text { vision }\end{array}$ \\
\hline & Video Analysis personal & $\begin{array}{l}\text { Recording and analysing } \\
\text { one's own performance in } \\
\text { practice }\end{array}$ & $\begin{array}{l}\text { Reveals any discrepancies } \\
\text { and mismatches between } \\
\text { expected behaviour and } \\
\text { actual behaviour }\end{array}$ \\
\hline & Video Analysis peer & $\begin{array}{l}\text { Analysing someone else's } \\
\text { video }\end{array}$ & $\begin{array}{l}\text { Confrontation with one's } \\
\text { own behaviour } \rightarrow \text { increases } \\
\text { one's understanding } \\
\text { of one's own behaviour }\end{array}$ \\
\hline & Video Analysis group & $\begin{array}{l}\text { Critical dialogue about } \\
\text { interpretations of the } \\
\text { observed behaviour based } \\
\text { on video clips }\end{array}$ & $\begin{array}{l}\text { Conceptual enhancement } \\
\text { and joint clarification of } \\
\text { concepts }\end{array}$ \\
\hline
\end{tabular}




\begin{tabular}{|l|l|l|l|}
\hline Learning support & General quality facilitator & $\begin{array}{l}\text { Asking reflective questions; } \\
\text { continue asking questions; } \\
\text { encouraging people to } \\
\text { explain carefully/elaborate; } \\
\text { flexible balance between } \\
\text { control and giving room; } \\
\text { targeted; } \\
\text { Summarize; do not judge, } \\
\text { appreciate. }\end{array}$ & $\begin{array}{l}\text { Facilitates (the courage to) } \\
\text { learn }\end{array}$ \\
\cline { 2 - 4 } & Studying theory & $\begin{array}{l}\text { Relevant sources } \\
\text { Time to read }\end{array}$ & $\begin{array}{l}\text { Acquisition of new } \\
\text { knowledge, encourages } \\
\text { reflection. }\end{array}$ \\
\cline { 2 - 4 } & $\begin{array}{l}\text { Formulating a personal } \\
\text { learning objective }\end{array}$ & $\begin{array}{l}\text { Help formulating a guiding } \\
\text { objective }\end{array}$ & $\begin{array}{l}\text { Provides focus for learning } \\
\text { and gives direction }\end{array}$ \\
\hline
\end{tabular}

Table 3. Active ingredients interventions

\section{Results research question two}

\section{Changes in beliefs}

After TIPP, participants in all four groups reported a change in beliefs with respect to the stimulation of IA-Internal (i.e. understanding, reflection and critical reflection). For IAExternal (i.e. knowledge-sourcing behaviour) $75 \%$ reported a change in beliefs in the interviews, while reflecting on the questionnaire and theory of practice .At a group level it was interesting to see that all four groups went through the greatest change in the beliefs regarding reflection and critical reflection. For knowledge sourcing the changes varied for each group, from a decrease of $20 \%$ to an increase of $75 \%$. One group stands out because its participants reported the lowest for all aspects during T1, however they reported $100 \%$ increase for all aspects during T2, with the exception of understanding. The results have been checked on the basis of background variables, but this does not explain this difference. 


\section{Changes in behaviour}

During TIPP the pattern of the behavioural repertoire with regard to encouraging IA-Internal (i.e. understanding, reflection and critical reflection) and IA-External (i.e. knowledgesourcing behaviour) hardly changed at a group level or at a participant level Interestingly, the two master groups had and maintained a richer behavioural repertoire than the bachelor groups .A different picture emerged when examining the frequencies of the interventions (see Table 4 and 5). We saw a substantial frequency increase in reflection and critical reflection. Zooming in on a group level, it became clear that this increase could be explained by one master group and one bachelor group. For the other interventions we could not establish notable (less than 2) frequency changes in any of the groups.

The virtual absence of changes in one master group can be explained by the fact that, at the start, the behavioural repertoire was broad and the frequencies were relatively high, and this situation did not change. The lack of changes in one of the bachelor groups was explained by its participants by the fact that their lessons primarily focus on theory without linking it to possible pedagogical approaches in the student's practice.

\begin{tabular}{|l|c|c|c|c|}
\hline \multicolumn{1}{|c|}{ Repertoire Time TIPP } & \multicolumn{2}{c|}{ Count } & \multicolumn{2}{c|}{ Cases } \\
\cline { 2 - 5 } & Video T1 & Video T2 & Video T1 & Video T2 \\
\hline Understanding & 38 & 36 & 13 & 12 \\
\hline Reflection & 46 & 80 & 13 & 12 \\
\hline Critical Reflection & 12 & 27 & 7 & 9 \\
\hline Knowledge Sourcing & 15 & 14 & 8 & 8 \\
\hline
\end{tabular}

Table 4. Overall changes in IA intervention frequencies

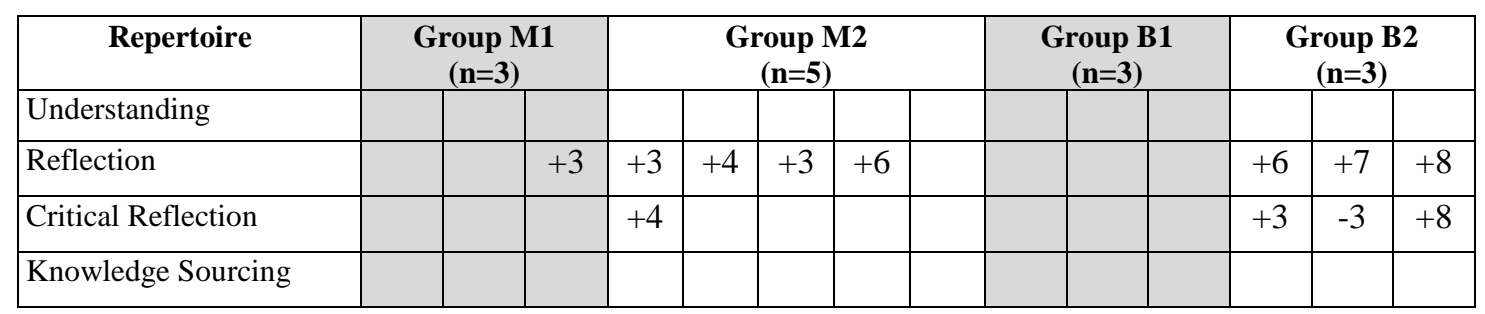

Table 5.. Group level changes in IA intervention frequencies 


\section{Conclusions and discussion}

This study wanted to explain to what extent and in what way a specifically designed professional development programme (TIPP) supports the transformative learning of experienced teacher educators' (TEs) with regard to stimulating an inquiry-based attitude (IA) in students. The design of TIPP was built on the following generic design principles: 'learning from and with peers', 'studying one's own beliefs and behaviour in practice' and 'learning support' (Hargreaves \& Fullan, 2012; Lunenberg et al., 2014; Van Veen, et al., 2010). The added value of the present research is the design of a specific intervention mix and a clarification of the active ingredients that support the intended development. The study also elucidates to what extent interventions influence changes in TEs beliefs and/or the behaviour in stimulating IA-Internal (i.e. understanding, reflection and critical reflection) or IA-External (i.e knowledge sourcing).

Although the specific value of the professional interventions is clarified, TIPP as a whole is more than the sum of its parts. As a whole the program contributes convincingly to transformative learning with regard to the beliefs relating to the stimulation of both IAInternal and IA-External. Our explanation is that an aligned mix between a trained facilitator and the intervention sets 'Theory of Practice' and 'Video Analysis' designed to support systematic self-study of professional beliefs and behaviour in combination with sharing, discussing and elaborating on the findings within a safe peer group stimulates professional learning at the level of transformative learning.

The intervention set 'Theory of Practice' confirms Kelchterman's theory (2009) that an explicit expression of one's personal theory of practice, creates an understanding of who one is and how one wants to be. Our research adds to this that sharing theories of practice with peers and combined with in-depth group discussion supports both transformative 
learning and the development of a shared vision. The intervention set 'Video Analysis' confirms that peer observations, combined with professional learning conversations, encourage critical reflection (Schuck et al., 2008). New in our research is the fact that the personal confrontation and elaborating on inconsistencies and discrepancies between intended and actual behaviour in particular contributes to transformative learning.

Noteworthy is that almost every participant defined specific facilitator qualities and emphasised the importance of these qualities in supporting personal and group learning, which is in line with the research of Lunenberg, Zwart \&Korthagen (2010). The explicit appreciation of the specific qualities of facilitators raises the question as to what extent the facilitator can be separated from the interventions. Also noteworthy was the lack of appreciation for the reflective memos and personal logs, even though personal logs are very common in teacher education. On the basis of theories this lack of appreciation is not easy to explain. Presumably it has to do with the specific mix of interventions, in which those interventions had no added value.

Although we see positive changes in the beliefs regarding IA-Internal in all groups, where behaviour is concerned, we only observe this in two groups. This discrepancy between beliefs and behaviour is a known phenomenon, but difficult to explain (Taylor, 2007; van der Schaaf, et al., 2008). Concerning IA-External it is conceivable that this discrepancy is affected by the situation in Higher Education in the Netherlands, where the emphasis is on working with prescribed theories. The question is to what extent this impedes the stimulation of IAExternal.

One master and one bachelor group hardly showed any behavioural changes. For the master group the behavioural repertoire and frequencies were already so optimal at the start that further improvements were almost impossible. For the bachelor group this was not the case, but it was notable that the focus of this educator's practice was on the transfer of 
knowledge and not on the intention to be a role model as a teacher as emphasised by Lunenberg et al. (2014) and Berry (2009). The positive causal relationship between changes in intentions and changes in behaviour (Webb \& Sheeran, 2006) might indicate that a greater emphasis on the educators' intention to be a role model as a teacher is an important condition to engender greater impact on educators behaviour. It was also notable that the master groups had a richer repertoire of behaviour and that they also utilised this more frequently than the bachelor groups. Furthermore, the group that scored the least at the start for all parts showed the greatest development. It may be worthwhile to check the extent of development that can be expected prior to participation in TIPP.

The main limitation of this study is the small sample size. However, by closely following the participants and triangulating behavioural observations with instruments with a self-reporting nature combined with facilitators' meetings where we discussed and monitored the research quality, we increased the validity and reliability. Nevertheless, the method of data collection may have played a role in our results. At the baseline the data collection consisted of a single source (theory of practice 1), the post-test consisted of multiple sources (theory of practice 2, questionnaire and interview). The use of the second practice theory as the source had particular restrictions because most participants merely added things to the first version. As a consequence, the interviews turned out to be a better source for exploring changes than the differences between the first and second theory of practice. However, the rewritten theories of practice showed that it is indeed important that it is taken seriously, because it 'forces' someone to reflect. In addition, although the relatively high average age of the TEs (50.8) is representative of our setting, the question is whether the results for younger and less experienced educators will be different.

For a more thorough understanding of the specific meaning of the studied interventions regarding the transformative learning of TEs, we advise that this study is scaled 
up to a large-scale study within and outside an educational context, also linking the results of TIPP to the results achieved for students. We also recommend performing research into the development of the IA of students during and after teacher education and an exploration of the extent in which IA development can be explained by background variables and personality traits. Finally, we recommend further investigation of the influence of the qualities of specific facilitators on transformative learning in other research on professional development interventions. 
Bibliography

Akister, J., Illes, K., Maisch, M., McKenzie, J., Ovens, P., Parker, J., et al. (2003). Learning from the Patchwork Text process-a retrospective discussion. Innovations in Education and Teaching International, 40(2), 216-226.

Argyris, C. (2004). Reasons and Rationalizations: The Limits to Organizational Knowledge: The Limits to Organizational Knowledge. Oxford, Oxford University Press.

Avalos, B. (2011). Teacher professional development in Teaching and Teacher Education over ten years. Teaching and teacher education, 27(1), 10-20.

Baldwin, C. Y., \& Clark, K. B. (2000). Design rules: The power of modularity (Vol. 1). Cambridge, Mit Press.

Beijaard, D., Meijer, P. C., \& Verloop, N. (2004). Reconsidering research on teachers' professional identity. Teaching and teacher education, 20(2), 107-128.

Berry, A. (2009). Professional self-understanding as expertise in teaching about teaching. Teachers and Teaching: theory and practice, 15(2), 305-318.

Biesta, G. (2007). Why “what works" won't work: Evidence-based practice and the democratic deficit in educational research. Educational theory, 57(1), 1-22.

Boekaerts, M. (1996). Personality and the psychology of learning. European Journal of Personality, 10, 377-404.

Bruggink, M., \& Harinck, F. (2012). De onderzoekende houding van leraren: wat wordt daaronder verstaan? Tijdschrift voor lerarenopleidingers, een gezamelijke uitgave van Velon-Velov, 47-48.

Cochran-Smith, M., \& Lytle, S. L. (2009). Inquiry as stance: Practitioner research for the next generation. Williston, Teachers College Press.

Cochran-Smith, M., \& Zeichner, K. M. (2010). Studying teacher education: The report of the AERA panel on research and teacher education: Lawrence Erlbaum Associates, London

Coonen, H. (2006). De leraar in de kennissamenleving: beschouwingen over een nieuwe professionele identiteit van de leraar, de innovatie van de lerarenopleiding en het management van de onderwijsvernieuwing. Apeldoorn, Garant.

Cuva, A. (2014). Connecting the Dots: A Review of Traversing the Uncharted Arena of Computer Assisted Qualitative Data Analysis Software: Mapping Out QDA Miner 4.1 as a First-Time User. The Qualitative Report, 19(51), 1-4.

Day, C., Kington, A., Stobart, G., \& Sammons, P. (2006). The personal and professional selves of teachers: stable and unstable identities. British Educational Research Journal, 32(04), 601-616.

Dengerink, J., Lunenberg, M., \& Kools, Q. (2015). What and how teacher educators prefer to learn. Journal of Education for Teaching, 41(1), 78-96.

Desmione, L. M. (2009). Improving Impact Studies of Teachers' Professional Development: Toward Better Conceptualizations and Measures. Educational Researcher, 38(3), 181199.

Dinkelman, T. (2011). Forming a teacher educator identity: uncertain standards, practice and relationships. Journal of Education for Teaching, 37(3), 309-323.

Dyment, J. E., \& O'Connell, T. S. (2011). Assessing the quality of reflection in student journals: a review of the research. Teaching in Higher Education, 16(1), 81-97.

Flores, M. A., \& Day, C. (2006). Contexts which shape and reshape new teachers' identities: A multi-perspective study. Teaching and teacher education, 22(2), 219-232.

Fukkink, R. G., Trienekens, N., \& Kramer, L. J. C. (2010). Video feedback in education and training: putting learning in the picture. Educational Psychology Review, 1-19.

Fullan, M., \& Langworthy, M. (2014). A rich seam: How new pedagogies find deep learning. 
Geijsel, F., \& Meijers, F. (2005). Identity learning: the core process of educational change. Educational Studies, 31(4), 419-430.

Gray, P. H., \& Meister, D. B. (2006). Knowledge sourcing methods. Information \& Management, 43(2), 142-156.

Hargreaves, A., \& Fullan, M. (2012). Professional capital: Transforming teaching in every school. Williston, Teachers College Press.

Hattie, J., \& Timperley, H. (2007). The power of feedback. Review of educational research, 77(1), 81-112

Hord, S. M. (1997). Professional learning communities: Communities of continuous inquiry and improvement. Austin, Southwest Educational development laboratory.

Illeris, K. (2009). Transfer of learning in the learning society : How can the barriers between different learning spaces be surmounted, and how can the gap between learning inside and outside schools be bridged?, International journal of lifelong education (Vol. 28, pp. 137-148).

Illeris, K. (2014). Transformative learning and identity. New York: Routledge.

Kelchtermans, G. (2009). Who I am in how I teach is the message: Self-understanding, vulnerability and reflection. Teachers and Teaching: theory and practice, 15(2), 257272.

Kember, D., Leung, D. Y. P., Jones, A., Loke, A. Y., McKay, J., Sinclair, K., et al. (2000). Development of a questionnaire to measure the level of reflective thinking. Assessment \& evaluation in higher education, 25(4), 381-395.

Kessels, J. W. M. (2012). Leiderschapspraktijken in een professionele ruimte. Inaugurele rede. In OU.NL Nederland.

Leeman, Y., \& Wardekker, W. (2014). Teacher research and the aims of education. Teachers and Teaching, 20(1), 45-58.

Leijnse, F., Hulst, F., \& Vroomans, L. (2006). Passie en precisie. Over de veranderende functie van hogescholen. TH\&MA-Tijdschrift voor Hoger Onderwijs \& Management, $5,47-54$.

Lethbridge, K., Andrusyszyn, M.-A., Iwasiw, C., Laschinger, H. K., \& Fernando, R. (2013). Assessing the psychometric properties of Kember and Leung's Reflection Questionnaire. Assessment \& Evaluation in Higher Education, 38(3), 303-325.

Leung, D. Y. P., \& Kember, D. (2003). The Relationship between Approaches to Learning and Reflection upon Practice. Educational Psychology: An International Journal of Experimental Educational Psychology, 23(1), 61-71.

Litman, \& Spielberger. (2003). Measuring Epistemic Curiosity and Its Diversive and Specificic Components. Journal of personality assessment, 80(1), 75-86.

Lunenberg, M., Zwart, R., \& Korthagen, F. (2010). Critical issues in supporting self-study. Teaching and Teacher Education, 26(6), 1280-1289.

Lunenberg, M., Dengerink, J., \& Korthagen, F. (2014). The Professional Teacher Educator. Roles, Behaviour, and Professional Development of Teacher Educators (Vol. 13). Rotterdam, Boston, Taipei: sense Publishers.

Martens, R. L. (2009). RdMC onderzoeksprogramma 2009-2011, Succesvol leven lang leren op de werkplek: onderzoek naar de praktijk van docentprofessionalisering: Heerlen: Open Universiteit, Ruud de Moor Centrum.

Mason, J. (2009). Teaching as disciplined enquiry. [Article]. Teachers \& Teaching, 15(2), 205-223.

McCrae, R. R., Costa Jr, P. T., Ostendorf, F., Angleitner, A., Hřebíčková, M., Avia, M. D., et al. (2000). Nature over nurture: temperament, personality, and life span development. Journal of personality and social psychology, 78(1), 173-186 
McKenney, S., \& Reeves, T. C. (2013). Conducting educational design research. New York, Routledge.

Meijer, M., Geijsel, F., Kuijpers, M., Boei, F., \& Vrieling, E. (2016). Exploring teachers' inquiry-based attitude. Teaching in Higher Education, 21(1), 64-78

Mezirow, J. (1991). Transformative dimensions of adult learning. San Francisco, Jossey-Bass.

Mezirow, J., \& Taylor, E. W. (2009). Transformative learning in practice: Insights from community, workplace, and higher education. San Francisco, Jossey-Bass.

Miles, M. B., Huberman, A. M., \& Saldaña, J. (2013). Qualitative data analysis: A methods sourcebook (3 ed.): SAGE Publications, Incorporated.

Mourshed, M., Chijioke, C., \& Barber, M. (2010). How the world's most improves school systems keep getting better. London: McKinsey \& Company.

Newberry, M. (2014). Teacher educator identity development of the nontraditional teacher educator. Studying Teacher Education, 10(2), 163-178.

OCW/EZ. (2009). Naar een robuuste kenniseconomie, Brief aan de Tweede Kamer.

Onderwijsraad. (2014). Meer innovatieve professionals. Den Haag.

Ovens, P. (2011). Developing inquiry for learning: Routledge.

Patton, M. Q. (2015). Qualitative Research \& Evaluation Methods (4 ed.). London: Sage Publications Ltd.

Reio, T. G., Jr., Petrosko, J. M., Wiswell, A. K., \& Thongsukmag, J. (2006). The Measurement and Conceptualization of Curiosity. Journal of Genetic Psychology, 167(2), 117-135.

Ropes, D. (2010). Organizing professional communities of practice. University of Amsterdam, Amsterdam.

Schuck, S., Aubusson, P., \& Buchanan, J. (2008). Enhancing teacher education practice through professional learning conversations. European journal of teacher education, 31(2), 215-227.

Segers, M., \& Dochy, F. (1999). Een nieuw onderwijsmodel voor het hoger onderwijs in theorie en praktijk. P. De Boeck \& M. Lacante (eds.), 153-180.

Snoek, M., Swennen, A., \& van der Klink, M. (2011) The quality of teacher educators in the European policy debate: actions and measures to improve the professionalism of teacher educators, Professional Development in Education, 37:5, 651-664,

Swanborn, P. (2010). Case study research: What, why and how? : London, SAGE Publications.

Taylor, E. W. (2007). An update of transformative learning theory: a critical review of the empirical research (1999-2005). International Journal of Lifelong Education, 26(2), $173-191$.

Taylor, E. W., \& Jarecke, J. (2009). Looking Forward by Looking Back. Reflections on the Practice of Transformative Learning. In J. Mezirow \& E. W. Taylor, and Associates (Eds.), Transformative Learning in Practice (pp. 275-289). San Fransisco: JosseyBass.

van Aken, J., \& Andriessen, D. (Eds.). (2011). Handboek ontwerpgericht wetenschappelijk onderzoek. den Haag: Boom Lemma uitgevers.

Van de Ven, A. H. (2007). Engaged scholarship: a guide for organizational and social research: a guide for organizational and social research: Oxford University Press.

Van den Akker, J., Gravemeijer, K., McKenney, S., \& Nieveen, N. (2006). Educational design research: New York, Routledge. 
van der Schaaf, M. F., Stokking, K. M., \& Verloop, N. (2008). Teacher beliefs and teacher behaviour in portfolio assessment. Teaching and Teacher Education, 24(7), 16911704.

Van Veen, K., Zwart, R., Meirink, J., \& Verloop, N. (2010). Professionele ontwikkeling van leraren: ICLON / Expertisecentrum Leren van Docenten.

Verkuyl, H., \& Korthagen, F. (1999). Kom je de leerlingen tegen of jezelf? Reflectie op de beroepsidentiteit als essentieel onderdeel van de lerarenopleiding. VELON Tijdschrift voor Lerarenopleiders, 21(3), 19-28.

Vermunt, J. D., \& Endedijk, M. D. (2011). Patterns in teacher learning in different phases of the professional career. Learning and Individual Differences, 21(3), 294-302.

Vijlder, F. d. (Ed.). (2007). Van klassieke professionals naar excellente organisaties. Amsterdam: Balans.

Webb, T. L., \& Sheeran, P. (2006). Does changing behavioural intentions engender behaviour change? A meta-analysis of the experimental evidence. Psychological bulletin, 132(2), 249. 